\title{
A COMPARISON WITHIN THE CONTEXT OF STRUCTURAL ANALYSIS: MOBY DICK and BLACK SWAN*
} (DÍĞER DILLE YAZILMIŞ MAKALE: İNGILIZCCE)

\author{
Mustafa ÖZAĞAÇ **
}

\begin{abstract}
ÖZ
Hem Balina kelimesinin ve hem de balerin kelimesinin etimolojik kökeni 'dönmek' fiiline işaret etmektedir. Bu ilgi çekici ortak anlam, kurgusal bir balina hikayesi anlatan Moby Dick romanı/filmi ile bir balerin hikayesi olan Black Swan filmi bağlamında daha da merak uyandırıcı bir durum arz eder. Zira Moby Dick ve Black Swan anlatılarının her ikisi de siyah-beyaz sembolizmi ve bu iki rengin karşıtlığı ve döngüselliği temelinde oluşturulmuştur. Yapısalcı analiz yöntemi söz konusu iki esere uygulandığında eserlerin derin yapıları görülebilmektedir. Yapısalcı analiz yöntemi bu yönüyle söz konusu iki eserin incelenmesi için elverişli bir kuram durumundadır. Zira yapısalcı bir bakış sayesinde, Moby Dick ve Black Swan'ın baş karakterlerin dairesel hareket eğilimlerini ve renk sembolizminin simetrik karşıtlığını birlikte gösterebilmek mümkündür. Makalenin sonuç kısmında bu simetrik yapı tek bir şema üzerinde izah edilmektedir. Yanı sıra makalede Black Swan'1n mitolojik arka planı ile Moby Dick'in Kutsal Kitaptaki arketipleri incelenmiştir.
\end{abstract}

\footnotetext{
Bu makale 05.11.2021 tarihinde dergimize gönderilmiş; 06.11.2021 tarihinde hakemlere gönderilme işlemi gerçekleştirilmiş; 16.11.2021 tarihinde hakem raporlarının değerlendirilmesi sonucu yayın listesine dâhil edilmiş ve 20.12.2021 tarihinde yayınlanmıştır. This article has been prepared as a result of the feedback after the presentation at the symposium titled Mythology in Our Literature, organized by Yeditepe University on May 4, 2016.

Makaleye atıf şekli; Mustafa Özağaç, A Comparison Within The Context Of Structural Analysis Moby Dick and Black Swan, Avrasya Beşeri Bilm Araştırmaları Dergisi, Cilt/Sayı: 1-1 (2021), Karabük 2021, s. 88-95.
}

ISSN 2791-9900/e-ISSN 2822-2253, DOI: 10.7596/abbad.20122021.005

** Arş. Gör. Dr. Mustafa Özağaç. İstanbul Üniversitesi, İlahiyat Fakültesi: Türk-İslam Edebiyatı A.B.D., İskenderpaşa Mah. Kavalalı Sok. No:1 Fatih İstanbul,Telefon : +90 2124400000 ; Dahili : 26705 mustafa.ozagac@istanbul.edu.tr, orcid 1d: 0000-0001-8249-3096 
Anahtar Kelimeler: Moby Dick, Black Swan, Yapısalcı Analiz, Sembolizm, Mitoloji.

\section{ABSTRACT}

The etymological origins of both whale and ballerina words refer to 'to whirl'. This interesting common meaning becomes more of a curiosity within the context of Moby Dick novel/movie, which tells a fictional whale story, and Black Swan movie, which is a ballerina story. Because the narratives of Moby Dick and also Black Swan are based on black and white symbolism and the contrast and circularity of these two colors. The deep structures of the stories can be seen when the structuralist analysis method is applied to both of them. Therefore, the structuralist analysis method is a convenient method in order to analyze these two works. Thanks to the structuralist view, it is possible to show that main characters' circular motion tendencies and symmetric contrast of color symbolism together. This symmetrical structure was explained on a single schema in the conclusion part of this article. In addition, the mythological background of Black Swan and the archetypes of Moby Dick in Holy Scriptures were analyzed.

Keywords: Moby Dick, Black Swan, Structuralist analysis, Symbolism, Mythology.

\section{Introduction}

Moby Dick is the name of Herman Melville's novel which has a substantial place in literature history. Moby Dick has been adapted into cinema several times but its 1956 version has been more popular than the others. On the other hand, Black Swan is a movie dated 2010. In the introduction part of Moby Dick, which is a masterpiece of Melville, the whale word is emphasized and analyzed with the help of various words: Whale - It originates directly from the Dutch and German word Wallen. Walw-ian, means to whirl, to roll. ${ }^{1}$ In addition to this cited information from Richardson Dictionary, Melville gives the equivalents of the word in different civilizations relaying that French 'Baleine' and Spanish 'Ballena' sayings to Whale.

Without this information given at the beginning of Moby Dick, this article probably would not have been written. To know the etymology of 'Whale' word caused a twirling chain of associations from 'whale' to 'ballerina' in my imagination, for there is no doubt on the relationship of -ballet and ballerina words and the act of whirl. Whale reminded me ballerina and ballerina reminded

Herman Melville, Moby Dick Beyaz Balina, çev. Sabahattin Eyüboğlu, Mina Urgan,Yapı Kredi Yayınları,İstanbul 2013, s. 28. 
me Black Swan; as a result I found myself watching Moby Dick (1956) and Black Swan (2010) movies twirling together in my mind.

According to Emel Kefeli, examining the relations between novel and cinema brings expansions in terms of methods and also provides opportunity for an inter-genre approach to the comparative literature field. ${ }^{2}$ In order to make a comparison between Moby Dick and Black Swan, I thought I should first search whether Captain Ahab in Moby Dick novel is described with black or connotations of this color or not. I envisaged a symmetrical study: since there was a White Swan against Black Swan, there should have been something related to 'black' against White Whale. I looked for this while reading the novel and I found exactly what I was looking for: Melville was depicting Ahab with black continuously- as it could be seen the citations from the novel below. To see the necessary plane in order to compare Black Swan and White Whale was crucial for the continuation of the study. I decided to include the mythological background of both works in comparison elements. By this way, my article evolved into the state of including both a structural comparison and the mythopoeic or archetypal method Moran mentioned in her criticism of this work. ${ }^{3}$

\section{The Mythological Background in Black Swan}

We can find the marks of basic archetypes of Black Swan in both Hebrew mythology and Greek mythology. Lily character in the movie evokes Lilith in Hebrew mythology. According to the mythology, Lilith is the woman created before Eve. She is created from the earth like Adam. Suggesting that she is equal with Adam, she refuses to unite with Adam in the prescribed manner and she ascends to the sky by saying the magic words of God. ${ }^{4}$ As a result of this, she suffers the wrath of God. Eve is created from Adam's rib on the other hand. The couple of Lilith and Eve in this story evoke the couple of Lily and Nina, therefore Black and White Swan. The common point of Lilith and Eve is that they are created as a partner to Adam by God. The difference of them is their origins: One is created from the earth; the other is created from Adam' rib. Whatever marks of the Black Swan in Greek mythology are, we encounter them in the story of Zeus and Leda. ${ }^{5}$ Zeus turns into a swan in order to unite with Leda. According to

2 Emel Kefeli, “Karşılaştırmalı Edebiyat: Tanım, Yöntem ve İncelemeler”,Türkiye Araştırmaları Literatür Dergisi, C.4, S.8, İstanbul 2006,s. 346).

BernaMoran,Edebiyat Kuramları ve Eleştiri,İletişim Yayınları,İstanbul 2012, s.219.

4 Robert Graves - Raphael Patai, İbrani Mitleri Tekvin-Yaratılış Kitabı,çev. Uğur Akpur, Say Yayınları, İstanbul2009, s103.

https://dailymythogies.wordpress.com/2011/03/04/mythology-in-the-film-black-swan/

11.01.2022, 22:00. 
legend, Leda's children Castor is from her husband; Polluks is from Zeus as a result of this unit. ${ }^{6}$ Aforementioned twins are the seeds that fell into the same womb from two different origins. In the Black Swan, two different origin archetypes in the same womb appear as Black and White twins.

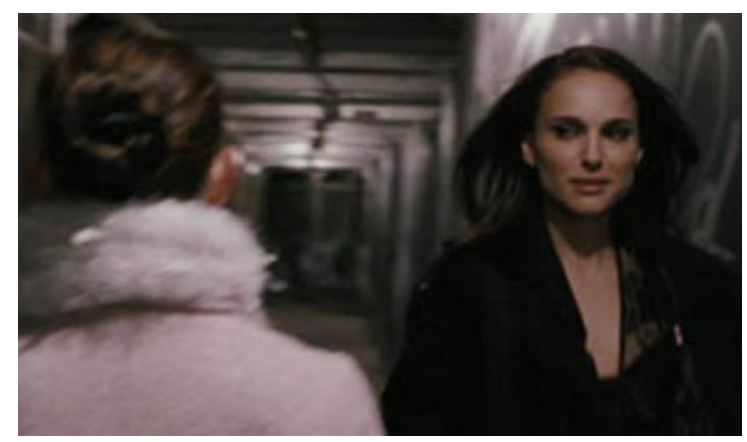

Black Swan, 2010. ${ }^{7}$

That the name of ballet director in the film is Thomas may probably relate to this ${ }^{8}$, because the etymological origin of the word gives us the $t$ win word $^{9}$.

\section{Archetypes of Moby Dick in Holy Scripture}

The anecdotes of Prophet Jonah in Holy Scriptures are told nearly 10 pages in Moby Dick. (Melville, 2013: 87). Prophet Jonah as a result of acting against the wish of Allah (God) is swallowed by the fish. After getting out from the stomach of the fish, he is almost as if he was born from/in the fish.

6 EdithHamilton, Mitologya, çev. Ülkü Tamer, Varlık Yayınları, İstanbul 2011,s. 25.

7 http://www.cornponeflicks.org/blackswan.html, 11.01.2022, 22:00.

8 http://tvtropes.org/pmwiki/pmwiki.php/Film/BlackSwan, 11.01.2022, 22:00.

9 https://www.etymonline.com/word/Thomas, 11.01.2022, 22:00. 


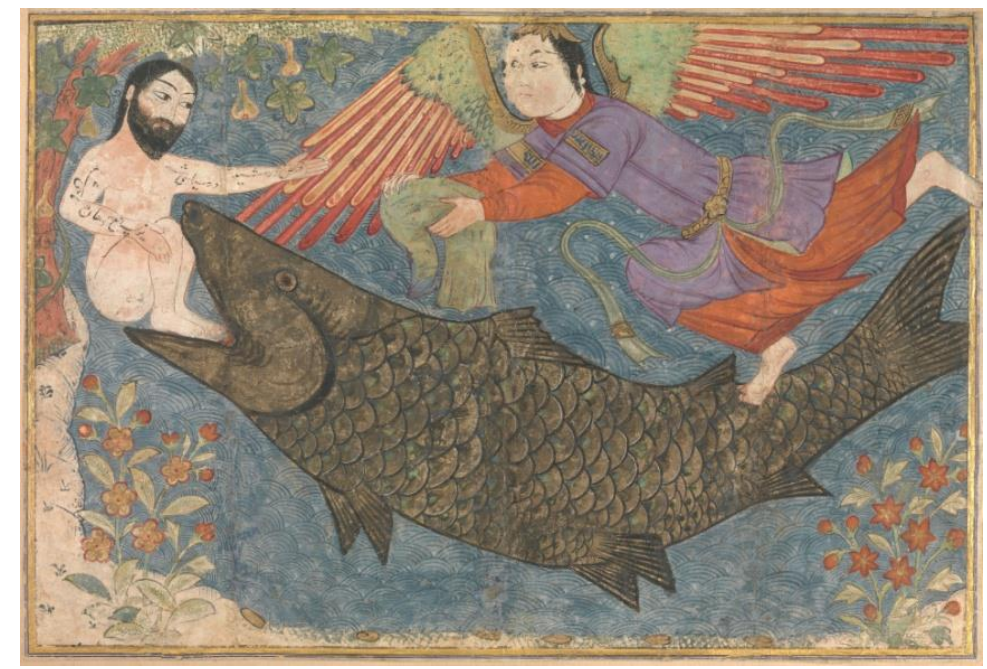

\section{Jonah and Whale ${ }^{10}$}

On the other hand, reversing these images, Melville tells the story of the man who dies in the fish against the man who is born in the fish. It can be said that Moby Dick is Melville's malignant and dark answer to the story of Prophet Jonah in Holy Scriptures.

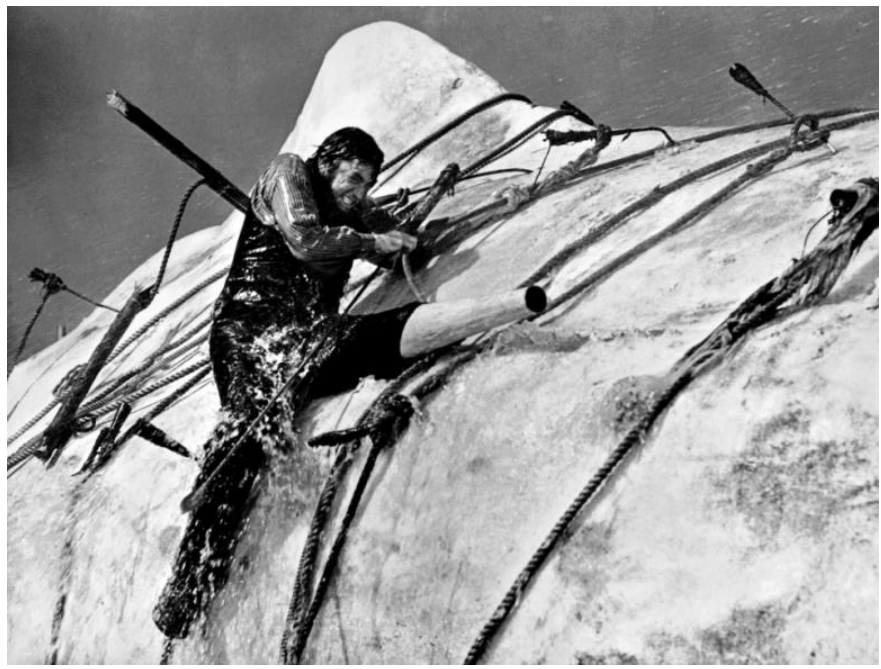

Moby Dick, 1956.(Hoberman: 02.10.2015) 
The name of the pagan Israel king mentioned in Kings Chapter 16:29 in the Torah is Ahab. This king is evil in the view of God.

\section{Comparison of Two Works with Structuralist Analysis}

In my comparison, I considered the novel of Moby Dick not the movie version of it against the movie of Black Swan. While not wanting to deal with the problems in transferring of the novel to the cinema, I must say that Melville's character descriptions provided me the necessary information for the color symbolism I looked for but the movie version of Moby Dick could not provide it exactly. The method to examine and compare the deep structures of Moby Dick and Black Swan is Structruralist Analysis method; because the Structuralist method provides getting into the text/work thoroughly and presenting the deep structure of the work that is not visible on the surface. ${ }^{11}$ I will try to show the result in a single schema after taking an X-ray of these two works and revealing the skeletal structure that is not visible at first glance. We aim to see the system which makes the organized rules of narrative elements when we look at it with the Structural perspective.

Thus we can see that various events can actually be condensed into a few categories, and various characters can be condensed into a few fixed roles. ${ }^{12}$ Even if one of X-rays belongs to a swan the other belongs to a whale, comparing them is relatively easy as both of them have only black and white lines. Ahab character in Moby Dick is created with the associations of 'black' and Nina character of Black Swan is created with associations of 'white'. Killing a white whale for Ahab and being a black swan as a life goal are the obsessions for the characters. An important aspect in this comparison is that both works are fictionalized on color symbolism. Melville often uses the 'black' word in order to describe Ahab:

I wouldn't think about Ahab's dark self. ${ }^{13}$

...seemed as sparging the black clouds in Captain Ahab. (180)

Dark faced, scary Ahab. (209)

Black hearted Ahab...is brooding over something closed to his cabin. (230)

He blacks out. (248)

We haven't seen the larger, darker, deeper sides of Ahab. (249)

Ahab is brooding over something. (250)

But the dark (black) spirit of Ahab. (265)

\footnotetext{
11 Ayşegül Yüksel,Yapısalcılık ve Bir Uygulama: M. Cevdet Anday Tiyatrosu, Gündoğan Yayınları, Ankara 1995, s.13.

12 Berna Moran, a.g.e. s. 196.

13 Melville, a.g.e, s. 131.
} 
There wasn't no living light in his eyes, however, this light that could enlighten nothing was darkness itself. (267)

Dark faced Ahab was standing among five black ghosts who appeared to from the air. (282)

...the storm clouds on his forehead dispersed. (388)

Along with all these considerations, Ahab's forehead was wrinkled and turned to a mess, like black sand gnawed by a storm. (466)

Each word to reveal the depths in Ahab was creating a meaningful darkness rather than an enlightening light. (558)

Damn to my black fortune. (670)

\section{CONCLUSION}

Moby Dick and Black Swan in which all the associations of 'Black' and 'White' are discussed are the products of Western Thoughts and have also mythological backgrounds. When we handle the two works together and get into their deep structures, we can see the movement and struggle of black and white and this is also expressed with the Yin-Yang circle in Taoism, which is an ancient thought. Both Whale and Ballerina words are originated from the Bale verb (to whirl) as explained beforehand and this is an important clue about the symbolism of the two works.

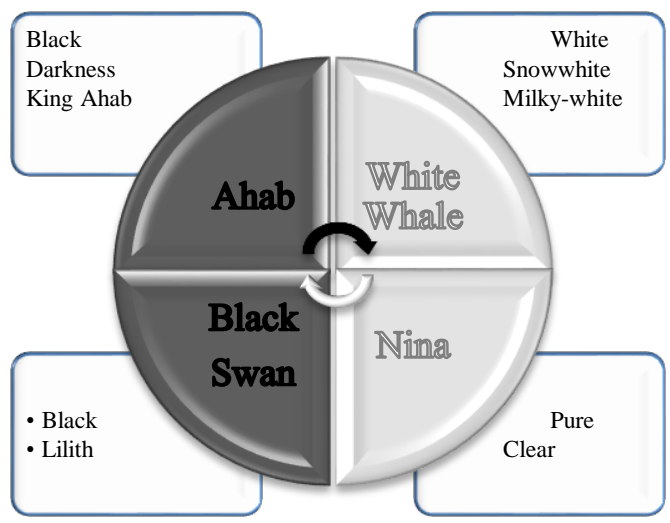

Abdülhamit Kirmızı points out that transformation can be provided with die in his writing on Black Swan. ${ }^{14}$ Black Swan and Moby Dick are the works as

14 http://www.hayalperdesi.net/sinefil/42-kimi-yasarsan-osun-ve-ancak-olumle-tamamlanirsin.aspx, 11.01.2022, 22:00. 
examples to this situation. However, Nina and Ahab who die as results of their passions and obsessions are the examples of Western philosophy. The standing reason of the cost of their transforms is being death. When it comes to transformation in Eastern philosophy, there is another possibility other than death: 'to be'.

Ah Muhsin Ünlü tells this difference between Eastern and Western Philosophy like this:

To keep Werther's way and to die moaning in blood.

Or

To keep Kays'way and to be listening in moments ${ }^{15}$

It can be seen in these two works we analyzed that characters keep Werther's way as in the poet's words.

\section{KAYNAKÇA}

DAIILY MYTHOGIES (11.01.2022, 22:00). Mythology in the film: Black Swan. https://dailymythogies.wordpress.com/2011/03/04/mythology-in-the-film-black-swan/

GRAVES, Robert-Raphael Patai, İbrani Mitleri Tekvin-Yaratılış Kitabı, çev. Uğur Akpur, Say Yayınları, İstanbul 2009.

HAMILTON, Edith, Mitologya, çev. Ülkü Tamer, Varlık Yayınları, İstanbul 2011.

HOBERMAN, J. (11.01.2022, 22:00). Obsession on the High Seas: John Houston's 'Moby Dick'. The New York Times, https://www.nytimes.com/2015/10/04/movies/homevideo/obsession-on-the-highseas-john-hustons-moby-dick.html

KEFELİ, Emel, "Karşılaştırmalı Edebiyat: Tanım, Yöntem ve İncelemeler”, Türkiye Araştırmaları Literatür Dergisi, İstanbul 2006, C.4, S.8, s. 331-350.

KIRMIZI, Abdülhamit (11.01.2022, 22:00). "Kimi Yaşarsan Osun ve Ancak Ölümle Tamamlanırsın”, http://www.hayalperdesi.net/sinefil/42-kimi-yasarsan-osun-ve-ancak-olumle-tamamlanirsin.aspx

MELVILLE, Herman, Moby Dick Beyaz Balina, çev. Sabahattin Eyüboğlu, Mina Urgan, Yapı Kredi Yayınları, İstanbul 2013.

METROPOLITAN MUSEUM OF ART (11.01.2022, 22:00). Jonah and The Whale. https://www.metmuseum.org/art/collection/search/453683

MORAN, Berna, Edebiyat Kuramları ve Eleştiri, İletişim Yayınları, İstanbul 2012.

MURRAY, Matt (11.01.2022, 22:00). Black Swan.

http://www.cornponeflicks.org/blackswan.html

15 Ah Muhsin Ünlü, Gidiyorum Bu, Sel Yayıncılık, İstanbul 2008,s. 33. 
ONLINE ETYMOLOGY DICTIONARY (11.01.2022, 22:00). Thomas.

https://www.etymonline.com/word/Thomas

TV TROPES (11.01.2022, 22:00). Film / Black Swan.

http://tvtropes.org/pmwiki/pmwiki.php/Film/BlackSwan

ÜNLÜ, Ah Muhsin, Gidiyorum Bu, Sel Yayıncılık, İstanbul 2008.

YÜKSEL, Ayşegül, Yapısalcılık ve Bir Uygulama M. Cevdet Anday Tiyatrosu, Gündoğan Yayınları, Ankara 1995. 